\title{
The U.S. Geological Survey Southwest Biological Science Center Sound Science to Serve the American Southwest
}

\begin{abstract}
Home to Arches, Grand Canyon, and Saguaro National Parks, among others, the American Southwest's landscapes are as fragile as they are iconic. Energy development, water security, and grassland restoration are important to the region as it experiences population growth and increased demand for resources. The U.S. Geological Survey's Southwest Biological Science Center provides sound scientific information to help identify effective management strategies for the Southwest's abundant natural resources and vast public lands. Research is focused on two key areas-dryland ecology and river science.
\end{abstract}

The American Southwest's aweinspiring yet delicate landscapesincluding those of Arches, Grand Canyon, and Saguaro National Parks - underscore the importance of the region's natural and cultural heritage to the Nation. The
Colorado River, which provides water and power to nearly 40 million people, bisects the Southwest on its route from the Rocky Mountains to the Gulf of California, creating crucial habitat for plant and animal species found nowhere else on Earth. Given the Southwest's stunning scenery, arid climate, and ample resources, it is no wonder that many of America's fastest growing population centers are located in this region, including Phoenix, Arizona; Las Vegas, Nevada; and Saint George, Utah. Making the tough decisions that are necessary to balance the needs of the Southwest's natural systems with those of the region's growing communities requires science-based solutions. The U.S. Geological Survey's Southwest Biological Science Center (SBSC) provides objective and timely scientific information that supports the effective management of the abundant natural resources and hundreds of millions of acres of public lands located in the Southwest. Natural resource managers and policymakers use the innovative tools that SBSC scientists develop to address priority management issues facing the region, including energy development, water security, and grassland restoration. To support managers who must determine how to both use and sustain Southwestern lands and resources, SBSC scientists focus their research on two key areas: dryland ecology and river science.

\section{Dryland Ecology}

Semi-arid and arid regions, collectively called drylands, are characterized by high temperatures and low and variable amounts of precipitation, generally less than 12 inches per year. Because dryland ecosystems comprise 171 million acres of public land in the Southwest, their management is a pressing issue for Federal resource managers.

Dryland systems are vulnerable to the large and rapid increases in temperature, drought, and human populations that are forecast for the Southwest. These ongoing changes are expected to result in more frequent extreme events - including wildfires, droughts, and floods - that will alter

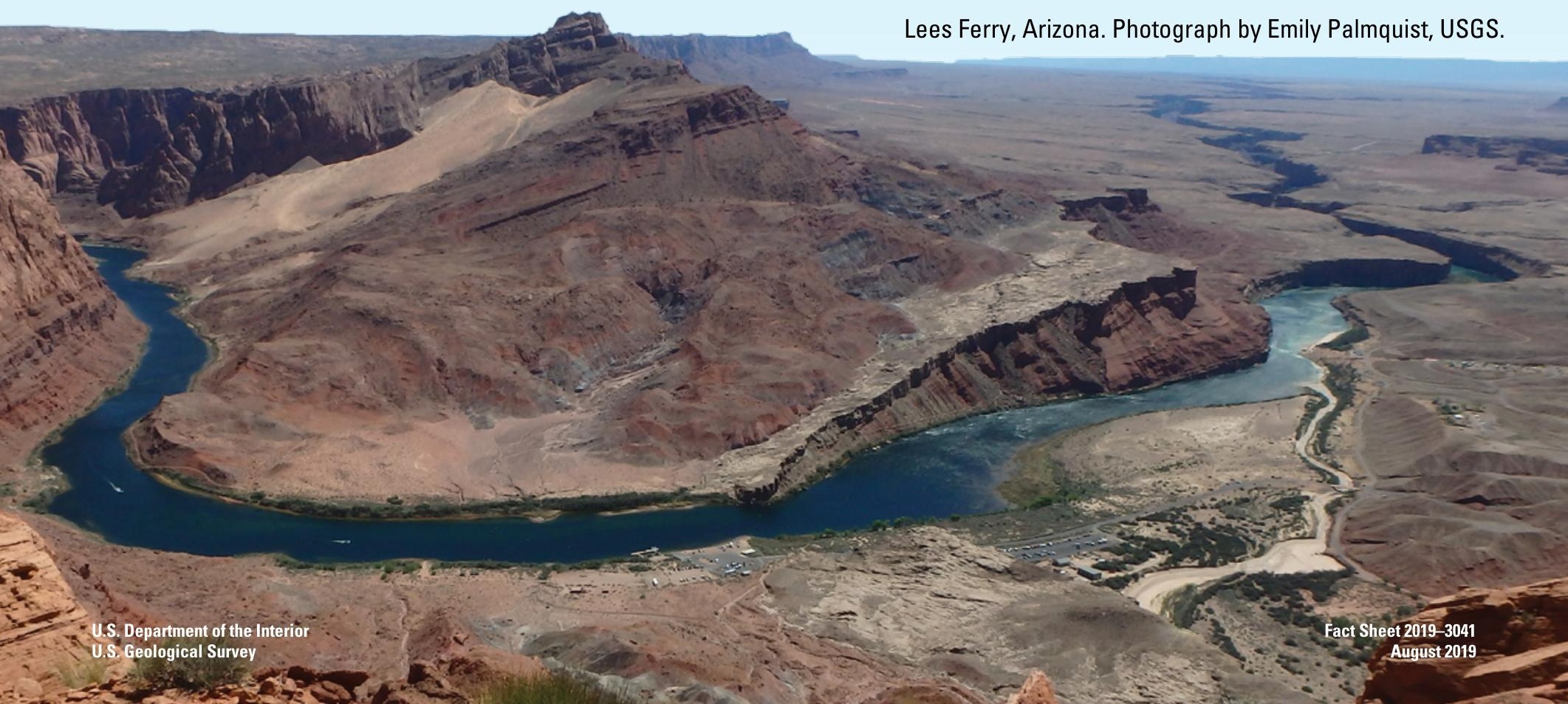


drylands and the ecological communities they support. Drylands are also susceptible to other challenges, such as invasive species, a legacy of overgrazing, and wind erosion, which can cause dust storms. These storms can damage crops, harm urban infrastructure, and raise the risk of traffic accidents by reducing visibility.

SBSC research identifies and supports new management strategies that enhance drylands' resilience in increasingly warmer and drier conditions and promote their recovery after resource development, invasions by exotic species, and droughts, wildfires, and other extreme events. Two examples of these efforts are highlighted below.

\section{Energy Development-An Automated Solution to Assess Reclamation Success}

Growing demand for energy resources and new extraction technologies have increased the exploration and development of Southwestern oil and gas resources as well as sites for solar, wind, and geothermal energy production. The Southwest Energy Development and Drought (SWEDD) program evaluates how past and present energy development has affected Colorado Plateau ecosystems and identifies ways that negative consequences can be mitigated.

Between 2000 and 2010, a twofold increase in the number of oil and gas wells on the Colorado Plateau disturbed large areas of vegetation and fragile biological soil crusts. During this time, the clearing and leveling of land to build oil and gas well pads, other large land disturbances, and drought helped raise regional levels of airborne dust. When this dust settled on the snow in the adjacent Rocky Mountains, its dark color relative to snow and ice caused the snowpack to melt earlier in the season. Earlier runoff, in some cases, reduced the regional water supply by as much as 5 percent (see Duniway and others, 2019, for more information).

To minimize airborne dust, restore wildlife habitat, and achieve improved air-quality objectives, land managers need to be able to identify disturbed lands and soils. Determining this information is no small task owing to the more than 90,000 wells that have been abandoned in the last 60 years of energy exploration across the 154-million acre Colorado Plateau. To meet this challenge, SWEDD scientists developed the Disturbance Automated Reference Toolset, which uses satellite images to compare the extent of vegetation cover at each well pad to nearby undisturbed reference sites. Areas with more exposed bare ground are more susceptible to soil erosion and dust emission (see Nauman and others, 2017, for more information).

Most of the abandoned oil and gas pads studied had more bare ground and less vegetation than surrounding undisturbed areas, despite more than 9 years of abandonment. Recovery has been uneven but was generally better on federally and privately managed lands. Additionally, well pads in grasslands, canyon complexes, blackbrush shrublands, and shale badlands have not recovered as well as other landscapes on the Colorado Plateau. These findings can help managers identify policies or procedures that may lead to improved well pad recovery.

\section{Science to Restore Damaged Lands}

Wildfire, drought, invasive species, historical overgrazing, and other disturbances can denude vegetation and degrade drylands, resulting in erosion and a substantial loss of ecosystem productivity. Since restoration can be difficult and expensive, and because these disturbances frequently cross administrative boundaries, SBSC scientists have long collaborated with land managers to develop solutions.

In 2012, for example, SBSC scientists and Federal land managers began testing restoration techniques in Canyonlands National Park to improve degraded grasslands in an area that had not recovered from the heavy cattle grazing of the mid1970s (prior to national park designation). Today, bare ground and nonnative species dominate some sites, leading to accelerated erosion. Small wire barriers, known as connectivity modifiers (or ConMods, for short), were tested for their ability to slow wind and water erosion enough to create favorable microsites to establish seedlings. In the first field trial, 90 percent of plots with ConMods successfully established native plants from seed, compared to 15 percent of plots without ConMods. The second phase of this project is currently testing whether the use of ConMods, combined with shallow raking and seeding, can successfully restore large areas of degraded grasslands in both Arches and Canyonlands National Parks.

Building on SBSC's growing expertise, the Restoration Assessment and Monitoring Program for the Southwest (RAMPS) was launched in 2016 to assist Federal, State, Tribal, and private land

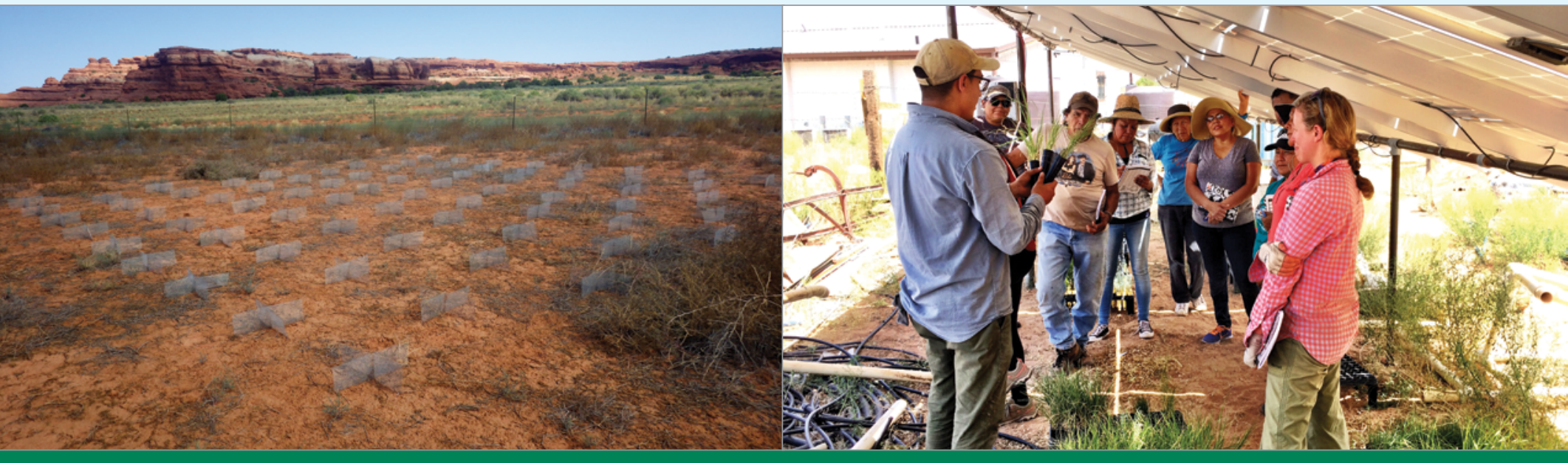

Participants in a workshop series on the Navajo Nation learn how to identify native plants as part of a restoration demonstration and experimental garden. Photograph by Molly McCormick, USGS. 
managers in developing appropriate restoration treatments for dryland ecosystems. Staffed by SBSC scientists, this U.S. Department of the Interiorfunded program is a hub for sharing information, science, and tools among 40 partner agencies and programs, including the National Park Service, Bureau of Land Management, and U.S. Fish and Wildlife Service.

For example, RAMPS scientists use medium-range climate forecasts to assist managers with selecting droughtadapted seeds and plants for restoration success, identify tools that support monitoring, and conduct hands-on training workshops. RAMPS scientists also analyze monitoring results, make site visits, and conduct experiments to identify practices that will improve restoration outcomes. At its core, RAMPS serves to connect scientists with land managers and strengthen collaboration.

\section{River Science}

In the desert Southwest, dependable supplies of clean water are vital to economic development, human health, and the region's prized wildlife and fisheries. The Southwest's lifeblood, the Colorado River, is the centerpiece of Grand Canyon and Canyonlands National Parks and one of the Nation's most important water and hydropower development projects.

Glen Canyon Dam, completed in 1963, impounds the Colorado River 15 miles above the start of Grand Canyon National Park. Operation of the dam has caused changes in the flow, temperature, and sediment-carrying capacity of the Colorado River, which, in turn, have caused narrowing rapids, beach erosion, expansion of riparian vegetation, and declines in native fishes, including the endangered humpback chub (Gila cypha). The protection of these resources emerged as a significant public concern in the decades following completion of the dam. In response, Congress passed legislation in 1992 that mandated a science-based approach to the dam's management. The SBSC's Grand Canyon Monitoring and Research Center (GCMRC) is responsible for the long-term data that policymakers and managers use to make effective, science-based decisions regarding the 293-mile-long segment of the Colorado River and its resources downstream of Glen Canyon Dam.

Monitoring and research performed by GCMRC scientists contribute to the goals of (1) increasing the number of endangered humpback chub and maintaining the populations of other native fish; (2) maintaining or improving sediment resources, including the sand that creates camping beaches for rafters and hikers; (3) protecting culturally important sites; (4) maintaining the aquatic food web upon which native and nonnative fish depend; (5) maintaining a high-quality sport fishery in the Lees Ferry reach; and (6) preserving native riparian vegetation communities.

\section{Balanced River Management- Coexisting Native and Nonnative Fish in Grand Canyon National Park}

The humpback chub is a species of native fish found only in the Colorado River Basin. Alterations to its habitat, caused primarily by the introduction of nonnative fish as well as changes in water flow, temperature, and turbidity from dam construction and operations, has resulted in severe population declines that led the U.S. Fish and Wildlife Service to list the humpback chub as endangered in 1967. Six years later, the species was given full protection under the Endangered Species Act of 1973.

Today, the largest of the six remaining populations of humpback chub is isolated in Grand Canyon. After dipping to a low of about 6,000 individuals, this population has stabilized at about 12,000 since 2009. Several coinciding factors appear to have given this population a boost. These include the release of warmer water from Glen Canyon Dam owing to ongoing drought conditions and a decrease in the abundance of nonnative fish, especially rainbow trout (Oncorhynchus mykiss) — a species that is economically important to the Lees Ferry sport fishery but can prey on juvenile humpback chub and outcompete them for food.

The inability to determine whether environmental factors or the fluctuating densities of nonnative fish populations have been most beneficial in stabilizing humpback chub in the Grand Canyon has hampered river-management decisions. To overcome this issue, SBSC researchers

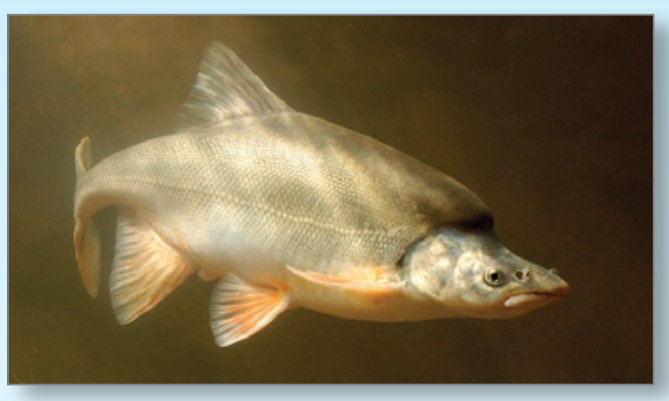

Humpback chub. Photograph by Randall D. Babb, Arizona Game and Fish Department.

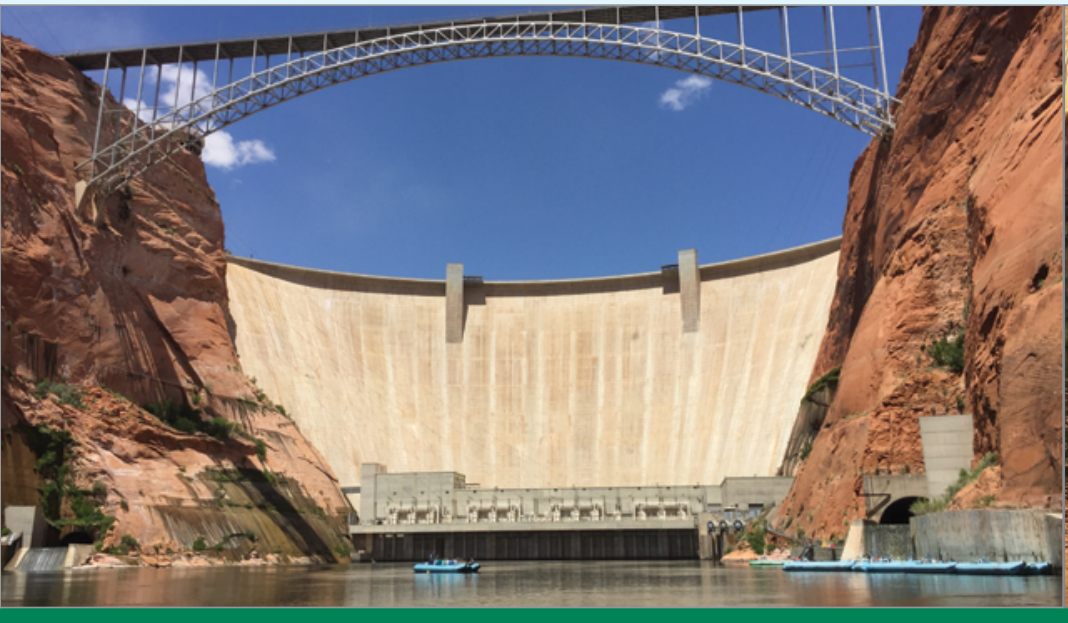

Glen Canyon Dam impounds the waters of the Colorado River above Grand Canyon National Park. Photograph by Todd Wojtowicz, USGS.

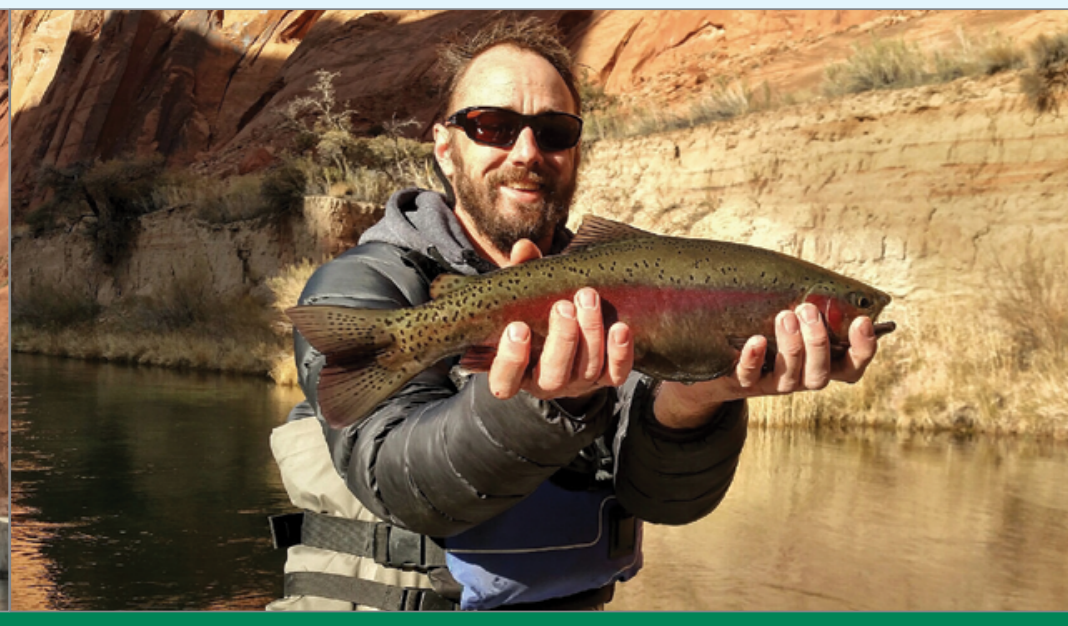

Rainbow trout caught in the trophy trout sport fishery at Lees Ferry, Arizona. Photograph by Morgan Ford, USGS. 
analyzed data from field studies of rainbow trout and juvenile humpback chub and developed computer models to forecast how both species might respond to different management alternatives.

The modeling data indicate that warmer water temperatures dramatically increase the growth rates of juvenile humpback chub, whereas higher abundances of rainbow trout decrease the survival of juveniles. The positive effect of warmer temperatures is equal to, and sometimes greater in magnitude, than the negative effects caused by rainbow trout. This novel modeling approach also has applicability to other systems (see Yackulic and others, 2018, for more information).

A better understanding of the factors responsible for stabilizing this federally endangered species has enabled the simultaneous management of rainbow trout, a species that is central to the $\$ 2.7$ million fishery at Lees Ferry, along with the conservation of the humpback chub.

\section{Tools for Managers}

Federal, State, Tribal, and private natural resource managers must make important decisions regarding complex natural systems in the context of competing views of resource use and highly uncertain outcomes. SBSC scientists gather and analyze data, develop novel predictive modeling approaches, and design innovative decision-support tools to facilitate natural resource decision making. Approaches advanced by SBSC scientists, such as structured decision-making and adaptive-management modeling, help managers clearly articulate objectives, recognize uncertainty, pinpoint tradeoffs, and identify the most effective and efficient outcomes of a range of management alternatives.

As highlighted above, SBSC scientists collected and analyzed data on humpback chub and rainbow trout and developed predictive models to address long-standing management questions in Grand Canyon. Modeling results allowed Bureau of Reclamation and National Park Service managers to estimate the effects of a range of proposed management actions for operating Glen Canyon Dam and select a preferred management alternative. Paired with new data, these same tools have recently been used by the National Park Service to evaluate options for responding to increasing brown trout (Salmo trutta) populations in Glen Canyon. Like rainbow trout, brown trout compete with native fish for food, but they are more aggressive predators of juvenile humpback chub. Sciencebased decisions such as these help to promote adaptive river-management strategies that balance economic and resource conservation goals.

\section{References Cited}

Duniway, M.C., Pfennigwerth, A.A., Fick, S.E., Nauman, T.W., Belnap, J., and Barger, N.N., 2019, Wind erosion and dust from US drylands - A review of causes, consequences, and solutions in a changing world: Ecosphere, v. 10, no. 3, 28 p., https://doi.org/10.1002/ecs2.2650.

Nauman, T.W., Duniway, M.C., Villarreal, M.L., and Poitras, T.B., 2017, Disturbance automated reference toolset (DART) Assessing patterns in ecological recovery from energy development on the Colorado Plateau: Science of the Total Environment, v. 584-585, p. 476-488, https://doi.org/10.1016/j. scitotenv.2017.01.034.

Yackulic, C.B., Korman, J., Yard, M.D., and Dzul, M., 2018, Inferring species interactions through joint mark-recapture analysis: Ecology, v. 99, no. 4, p. 812821, https://doi.org/10.1002/ecy.2166.

By Southwest Biological Science Center staff Edited by Monica Erdman

Layout and design by Cory D. Hurd

For more information, contact: U.S. Geological Survey

Southwest Biological Science Center 2255 N. Gemini Dr., Flagstaff, AZ 86001 Scott VanderKooi, Director (928) 556-7094

ISSN 2327-6916 (print) ISSN 2327-6932 (online) https://doi.org/10.3133/fs20193041

USGS Research Ecologist Mike Duniway shares drought experimental results with a National

Park Service ecologist, USGS ecologist, and local rancher. Photograph by Erika Geiger, USGS.

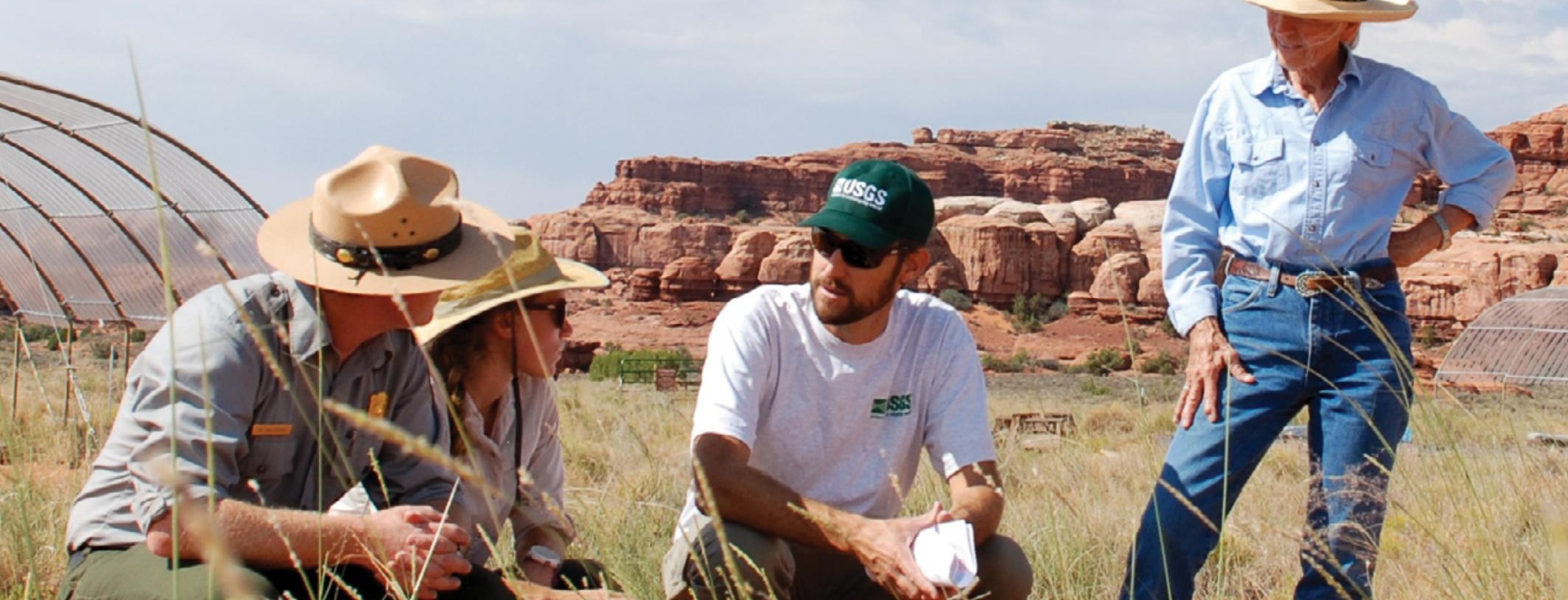

